\title{
ELECTROLYSIS OF SWINE MANURE EFFLUENTS USING THREE DIFFERENT ELECTRODES Fe-Fe, Al-Al AND Fe-Al
}

\author{
S. Rahman and M.S. Borhan \\ Agricultural and Biosystems Engineering, North Dakota State University, Fargo, North Dakota
}

Received 2014-07-24; Revised 2014-09-10; Accepted 2014-10-04

\begin{abstract}
Swine effluent with high organic strength need to be treated to make it suitable for applying to crop/pasture fields, or discharging to any waterways. Electrocoagulation is a relatively simpler and cheaper technique over biological and chemical treatment methods currently used to treat high-strength industrial and municipal wastewater. The performance of an electrocoagulation system mainly depends on the $\mathrm{pH}$, Electrical Conductivity (EC) of the medium, Chemical Oxygen Demand (COD) loading rates and catalytic activity of the electrodes used. In this research, a study was conducted to compare the pollutant removal efficiencies of three electrodes (Fe-Fe, $\mathrm{Al}-\mathrm{Al}$ and $\mathrm{Fe}-\mathrm{Al})$ with three electric current levels $(500,1000$ and $2000 \mathrm{~mA}$ ) while treating swine manure effluents. The electrochemical cell consisted of two parallel rectangular plates $(90 \times 25 \times 1.5 \mathrm{~mm})$ of Iron $(\mathrm{Fe}-\mathrm{Fe})$, Aluminum (Al-Al) and Iron-Aluminum (Fe-Al, later on described as hybrid) electrodes; immersed in a beaker with $550 \mathrm{~mL}$ swine effluents and powered by a Direct Current (DC) supply. All studies were conducted in batches at room temperature. In general, removal efficiencies were increased with increasing current densities and electrolysis times for electrodes evaluated. Aluminum electrodes outperformed iron and hybrid (iron-aluminum electrodes) in removing Total Phosphorus (TP) at all current density levels tested. Overall, use of hybrid electrodes resulted in better COD removal. For the same treatment times $(1200 \mathrm{~s})$ at higher current density $\left(21 \mathrm{~mA} \mathrm{~cm}{ }^{-2}\right)$, hybrid electrodes removed about $100 \%$ COD, which are about 1.9 and 1.3 times higher than those of aluminum and iron electrodes, respectively. Iron electrodes showed the highest removal efficiency (85\%) for Total Organic Carbon (TOC) at $21 \mathrm{~mA} \mathrm{~cm}^{-2}$ current density and $1200 \mathrm{~s}$ treatment time. Overall, lower Specific Electrical Energy Consumptions (SEECs) per kg of Pollutants (TP, COD and TOC) were estimated for the aluminum electrodes than the other electrodes combination.
\end{abstract}

Keywords: Total Phosphorus, Chemical Oxygen Demand, Total Organic Carbon, Manure Effluent, Electrode

\section{INTRODUCTION}

Nutrient management, especially phosphorus and nitrogen, of livestock liquid manure is a challenge due to their environmental impact potential on waters. If these nutrients from liquid manure can be removed and recovered, runoff potential of nutrients from livestock production facility or from land application of manure may be reduced. Also, recovered nutrients many be applied to crop later on. Phosphorus (P) is one of the essential nutrients for life, however, phosphate rocks are limited in the world and around $80 \%$ of phosphate produced globally is used as fertilizers (Regy et al., 2002; Udert et al., 2006; Inan and Alaydın, 2014). Due to limited phosphate supply, efforts to reduce nutrient loading, especially phosphorus, from livestock manure and runoff are ongoing. The development of $\mathrm{P}$ removal and recovery may provide phosphorus sustainability (Morse et al., 1998).

There are many options for nutrient removal such as evaporation, reverse osmosis, nitrification, precipitation,

Corresponding Author: S. Rahman, Agricultural and Biosystems Engineering, North Dakota State University, Fargo, North Dakota Tell: 701-231-8351; Fax: 701-231-1008 
ammonia stripping, electro dialysis and advanced oxidation (Inan and Alaydın, 2014). However, P removal technologies are limited. Biological P removal, chemical precipitation and crystallization techniques are the most common methods used to remove $\mathrm{P}$ from wastewater (Morse et al., 1998). Chemical precipitation is a flexible approach and can be applied at several stages of the wastewater treatment process as required (Morse et al., 1998). This process, however, precipitates P-bound waste and the impact of disposing this waste to agricultural land is not well documented. In the biological process, the use of chemical may be avoided, but it requires complex plant configuration. In addition, some novel technologies such as ion exchange, struvite crystallization, magnetic attraction, electrolysis and sorption have been studied to remove P (Liang, 2011; Cho et al., 2010). Electrolysis is a modern process of wastewater treatment and studied it to treat swine liquid manure in this study.

The electrolysis process works on the principal of oxidative or reductive chemistry and it needs relatively simple equipment at ambient temperature and pressure. The key process in electrolysis is the interchange of atoms and ions with addition or removal of electrons from an external source (Cho et al., 2010). However, electrolysis efficiency depends on the electrode materials, electric current density, pH, etc. ( $\mathrm{Li}$ and Liu, 2009; Liu et al., 2009; Cho et al., 2010). Researchers are using different electrode materials to optimize the system. In this study three different electrodes such as Iron ( $\mathrm{Fe}-\mathrm{Fe})$, Aluminum (Al-Al) and Iron-Aluminum (Fe-Al) electrodes were tested to improve the quality of swine wastewater.

The main objective of the present study is to investigate the electrochemical oxidation of swine effluent obtained from a primary lagoon for reducing organic and inorganic pollutants. The specific objectives are (1). to compare the pollutants (TP, COD and TOC) removal efficiencies of Iron (Fe-Fe), Aluminum (Al-Al) and Hybrid (Fe-Al) electrodes from swine effluents at varying currents and treatment durations, (2) to estimate the Electrical Energy Consumption (EEC) per unit volume of effluents treated and (3) to determine constituents and characterize sludge formed after electrolysis process.

\section{MATERIALS AND METHODS}

\subsection{Swine Effluents}

Liquid swine manure effluent was obtained from a primary lagoon of swine research unit at North Dakota State University, Fargo, North Dakota and were stored until analysis at $4^{\circ} \mathrm{C}$. Before a batch experiment was initiated, the effluent was homogenized and characterized for the following parameters: Electrical Conductivity (EC), pH, Total Suspended Solids (TSS), Total Phosphorus (TP), Chemical Oxygen Demand (COD) and Total Organic Carbon (TOC). Properties of tested swine effluents were presented in Table 1. In this study, no additives were used and no $\mathrm{pH}$ adjustment was made to swine manure effluent for enhancing electrolytic efficiency of the electrolyte. This study was aimed to treat the livestock wastewater in situ (at the generation and storage level) as an effective primary treating tool without any extra treatment cost.

\subsection{System Description and Operation}

In this experiment, a pair of parallel plate of three different electrodes such as Iron (Fe-Fe), Aluminum (Al-Al) and Hybrid (Fe-Al) were (wired as monopolar connection) tested in batches at room temperature around $25 \pm 2^{\circ} \mathrm{C}$. The electrochemical cell was consisted of two parallel rectangular plate electrodes $(200 \times 25 \times 1.5 \mathrm{~mm})$ immersed to a depth of $90 \mathrm{~mm}$ in a $550 \mathrm{~mL}$ swine effluents contained in cylindrical glass beaker (Fig. 1). The total effective area of anode and cathode electrodes under wastewater in the beaker was $96 \mathrm{~cm}^{2}$. The gap between anode and cathode plates was maintained at 8 mm using Teflon spacers and mounted vertically with the help of clamp. At the beginning of a run, the electrodes were placed into the swine effluent and electrodes were powered by a regulated DC powered supply (Model BK-1621 A, 0-18;0-5 A; BK Precision, Yorba Linda, CA) equipped with both ammeter and voltmeter displaying the current passing through the circuit and the cell voltage, respectively. To avoid electrode passivation and any contamination, electrodes were cleaned at the end of each treatment run by rinsing in diluted $\mathrm{HCl}(5 \% \mathrm{v} / \mathrm{v})$ solution. The polarity of electrodes was reversed every $300 \mathrm{~s}$ to prevent the formation of a passive layer on the electrode surface that reduces the efficiency of the electrolysis system. Polarity reversing also increases the longevity of the electrodes by ensuring equal wearing of anodes and cathodes. During electrolysis, the effluent under treatment was homogenized by gentle magnetic stirring at 200-300 rpm. A stirring intensity of 200-300 rpm was used in order to get a correct homogenization of the wastewater-flocs mixture. 
Table 1. Characteristics of swine effluents used in the experiments

\begin{tabular}{lll}
\hline Parameters & Measured concentrations & NDPDES discharge permit limit \\
\hline $\mathrm{pH}$ & $8.3 \pm 0.1$ & $6.0-9.0$ \\
Electrical Conductivity $\left(\mathrm{mS} \mathrm{cm}^{-1}\right)$ & $6.7 \pm 0.1$ & 0.9 \\
$\mathrm{TSS}\left(\mathrm{mg} \mathrm{L}^{-1}\right)$ & $980 \pm 50$ & $100(50)$ \\
$\mathrm{TP}\left(\mathrm{mg} \mathrm{L}^{-1}\right)$ & $35.3 \pm 3.1$ & 2.0 \\
$\mathrm{TOC}\left(\mathrm{mg} \mathrm{L}^{-1}\right)$ & $490 \pm 13$ & - \\
$\mathrm{COD}\left(\mathrm{mg} \mathrm{L}^{-1}\right)$ & $1577 \pm 110$ & 120 \\
Copper $\left(\mathrm{mg} \mathrm{L}^{-1}\right)$ & $\mathrm{DM}^{*}$ & 0.1685 \\
Arsenic $\left(\mathrm{mg} \mathrm{L}^{-1}\right)$ & $\mathrm{DM}$ & 0.0636 \\
Zinc $\left(\mathrm{mg} \mathrm{L}^{-1}\right)$ & $\mathrm{DM}$ & 0.117 \\
\hline
\end{tabular}

- NDPDES (2009) discharge limit for storm water from industrial activity (NDR09-0000); - ${ }^{*} \mathrm{DM}=$ didn't measured in manure
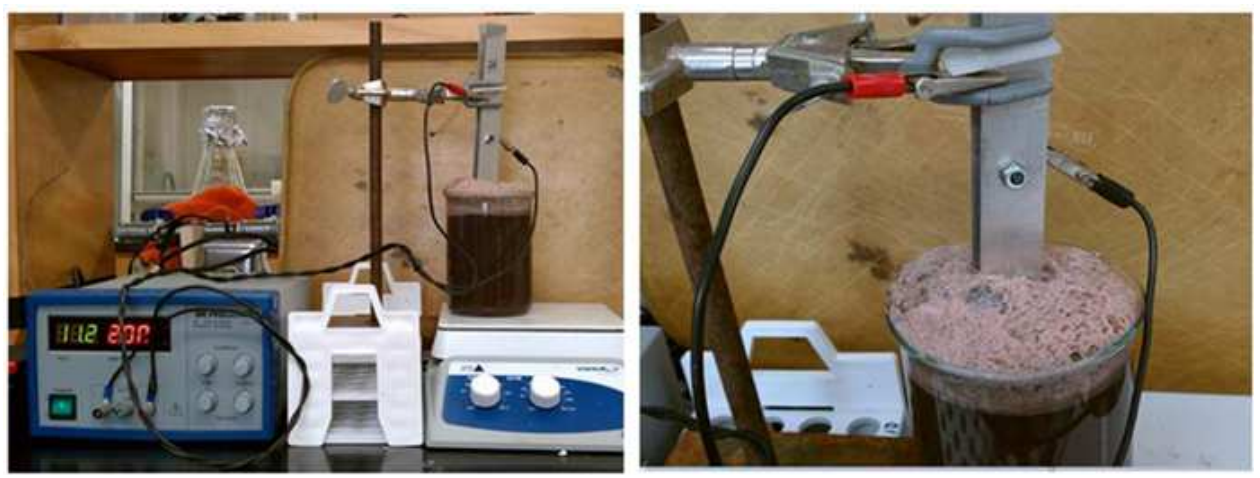

Fig. 1. Photograph of the laboratory scale electrolysis experiment set up taken from this research

\subsection{Treatment}

The overall performance and economy of an electrocoagulation process mainly depends on applied energy. Based on the EC of swine manure effluent used in this study, the maximum possible current that could be applied was $2000 \mathrm{~mA}$. Therefore, three current levels $(500,1000$ and $2000 \mathrm{~mA}$ ) were tested with three replicates to investigate the effect of applied current on the efficiency of electrocoagulation process for treating swine effluent. The current density levels were about 5, 10 and $21 \mathrm{~mA} \mathrm{~cm}^{-2}$, which was calculated by dividing applied currents with effective electrodes area immersed under wastewater. Electrolysis process was continued for a period of $3600 \mathrm{~s}$ at each current density.

\subsection{Sampling and Analysis}

Electrolyzed wastewater samples were sampled at five predetermined intervals $(300,1200,1800,2400$ and $3600 \mathrm{~s}$ ) to investigate electrolysis duration on nutrients removal. At the end of each time interval, about $10 \mathrm{~mL}$ of supernatant sample was removed using a pipette and stored in test tubes to settle suspended particles overnight before analysis was initiated. No centrifuging or filtration of samples was carried out followed by the electrolysis. Supernatant of the wastewater samples before and after electrolysis treatments were analyzed for TP, COD, TOC, pH and EC using Standard method of water and wastewater analysis (APHA, 2005). The $\mathrm{pH}$ and EC were analyzed using a hand held Orion $\mathrm{pH}$ and EC meter (Model, 990). Hach methods 10127, 8000 and 10173 were followed to determine TP, COD and TOC contents, respectively, in the sample before and after the electrolytic treatments. All analyses were performed calorimetrically using a HACH Model DR/2800 spectrophotometer (HACH Company, USA). All chemical used in the analyses were analytic grade. Analyses were performed in Waste Management Laboratory of North Dakota State University.

\subsection{Sludge Characterization}

At the end of electrocoagulation period, the floating scum buildup at the surface of electrolysis water was scraped and removed. The remaining treated (electrolyzed) wastewater was allowed to settle 
overnight. Then, settled sludge was filtered (Whatman, $11 \mu \mathrm{m}$ pore size) and oven dried at $103 \pm 2^{\circ} \mathrm{C}$ until the weight of the sludge samples were stabilized. A composite sample was made using the sludge from three replicates for each current density and electrodes type. The dried sludge was stored in a desiccators until analysis was completed. The sludge formed during electrolysis process was characterized by Inductively Coupled Plasma spectroscopy (ICP) using a 2010-11-15 Standard Method in the Wet Ecosystem Lab at North Dakota State University.

\subsection{Removal Efficiency (RE)}

The REs for TP, COD and TOC concentrations were calculated using the following relationship (Equation 1):

$R E=\frac{C_{i}-C_{f}}{C_{i}} \times 100$

where, $R E, C_{i}$ and $C_{f}$ are removal efficiency (\%), initial and final concentrations (ppm) of the pollutant under investigation.

\subsection{Electrical Energy Consumption (EEC)}

The EEC $(\mathrm{kWh})$ per unit volume $(Q)$ was calculated using following relationship (Equation 2):

$$
E E C=\frac{V I t}{3600 \times Q_{\text {inf luents }}}
$$

Where:

$I=$ Operating current $(\mathrm{mA})$

$t=$ Electrolysis time (s)

$V=$ Applied cell volt

$Q=$ Volume (L) of manure effluent treated

\subsection{Statistical Data Analysis}

Measured pollutants (EC, pH, P, COD and TOC concentrations) concentrations and calculated REs in each treatment (current level) run were compared using Analysis Of Variance (ANOVA). The null hypothesis tested was that mean measured pollutant concentrations and RE among various current levels (treatments) were equal. All statistical analyses were performed in the SAS environment using the PROC Means procedures (SAS, 1999). Mean concentrations and RE were then separated using Duncan's Multiple Range Test (Steel et al., 1997) at $5 \%$ significance level $(\mathrm{p} \leq 0.05)$ if the main effect (month) was significant using $F$ test at $\mathrm{p} \leq 0.05$.

\section{RESULTS}

Table 1 shows the initial characteristics of the swine manure effluent used in this research. The effluent had high organic strength (COD $\left.>1,000 \mathrm{mg} \mathrm{L}^{-1}\right)$, TP $(>35$ $\left.\mathrm{mg} \mathrm{L}^{-1}\right)$ and TOC (>490 $\left.\mathrm{mg} \mathrm{L}^{-1}\right)$ according to NDPDES (2009) discharge limit. Therefore, the swine effluent must be treated before applying to crop/pasture fields or discharging to any water streams. Removal of nutrients using the electro-coagulation method is strongly dependent on the EC of the aqueous medium. In addition, $\mathrm{pH}$, particle size, COD loading rates, electrodes nature and area and catalytic activity of the anodes also affect the process. In this study, $\mathrm{pH}$ and EC were measured twice; just before applying the power to the system and after $3600 \mathrm{~s}$ of electrolysis treatment time. Measured initial $\mathrm{pH}$ and EC were $8.3 \pm 0.1$ and $6.7 \pm 0.1$ $\mathrm{mS} \mathrm{cm}{ }^{-1}$, respectively.

\subsection{Effect of Treatment Duration on Pollutants Removal Efficiency}

The removal efficiencies of all pollutants (TP, COD and TOC) under investigation at different current densities, treatment times and electrode types were presented (Fig. 2 to 4). The REs of TP increased with all electrode combinations at varying current densities (5-21 $\mathrm{mA} \mathrm{cm} \mathrm{cm}^{-2}$ ) as treatment times progressed. At higher current density $\left(21 \mathrm{~mA} \mathrm{~cm}^{-2}\right)$, Fe-Al electrodes had shown better TP removal efficiency than other electrodes within $1200 \mathrm{~s}$ of treatment initiation (Fig. 2a), but at lower current densities ( 5 and $10 \mathrm{~mA} \mathrm{~cm}{ }^{-2}$ ) Al-Al electrodes outperformed the other electrodes for TP removal (Fig. 2b and c). TP removal progressed overtime, maximum TP removal occurred within 1800 $\mathrm{S}$ from the start of each experiment. Overall, Al-Al electrodes resulted in better TP removal over all current densities during the experimental period.

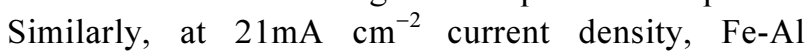
electrodes removed about $100 \%$ of COD within $1200 \mathrm{~s}$ of the process began (Fig. 3a), but at 5 and $10 \mathrm{~mA}$ $\mathrm{cm}^{-2}$ current densities COD removal efficiency for $\mathrm{Fe}-$ AL electrodes reached $\sim 80 \%$ in $3600 \mathrm{~s}$ (Fig. $3 \mathrm{~b}$ and c). At $10 \mathrm{~mA} \mathrm{~cm}{ }^{-2}$ current density, Fe-Fe electrodes showed better COD removal efficiency than other electrodes combination. Overall, the Fe-Al electrodes resulted in better COD removal (Fig. 3). 


\subsection{Effect of Current Densities, Treatment Times and Electrode Types on Pollutants Removal Efficiency}

Current density is one of the most crucial and steerable factors that control electrolytic treatment. In this study, electrode spacing was fixed at $8 \mathrm{~mm}$, but current densities were varied at three preselected levels using a DC power source equipped with ammeter and voltmeter displays. The voltage level fluctuated, which was obvious due to oxidation and ionization at the anode surfaces and minimized by reversing the polarity every $300 \mathrm{~s}$. For each current level, voltages were recorded at $300 \mathrm{~s}$ intervals during the $3600 \mathrm{~s}$ electrolysis period; an average of 12 voltage values was used to calculate the energy requirement. As with increased treatment duration, increased current densities demonstrated similar proportional effects on the RE sand Electrical Energy Consumption (EEC) described as follows.

The removal efficiencies of TP, COD and TOC were positively correlated with increasing treatment times and three levels of current densities $\left(5,10\right.$ and $\left.21 \mathrm{~mA} \mathrm{~cm}^{-2}\right)$ and treatment times for each electrode type (Fig. 2 to 4). Removal efficiencies of TP for all three electrodes ( $\mathrm{Fe}-\mathrm{Fe}$, Fe-Al and Al-Al) were similar (90 to $100 \%$ ) at $21 \mathrm{~mA} \mathrm{~cm}^{-2}$ current densities for a $1200 \mathrm{~s}$ treatment time (Fig. 2a). Removal efficiencies of TP during 1800s treatment time for all three electrodes at $21 \mathrm{~mA} \mathrm{~cm}^{-2}$ current density were about $100 \%$. The TP removal efficiency with Al-Al electrodes was about $100 \%$ at 1800 streatment time for all three levels of applied current densities (Fig. 2). Even at lower current density $\left(5 \mathrm{~mA} \mathrm{~cm}^{-2}\right)$, removal efficiencies of TP with Al-Al electrodes was higher than those of $\mathrm{Fe}-\mathrm{Fe}$ and $\mathrm{Fe}-\mathrm{Al}$ electrodes (Fig. 2b and c).

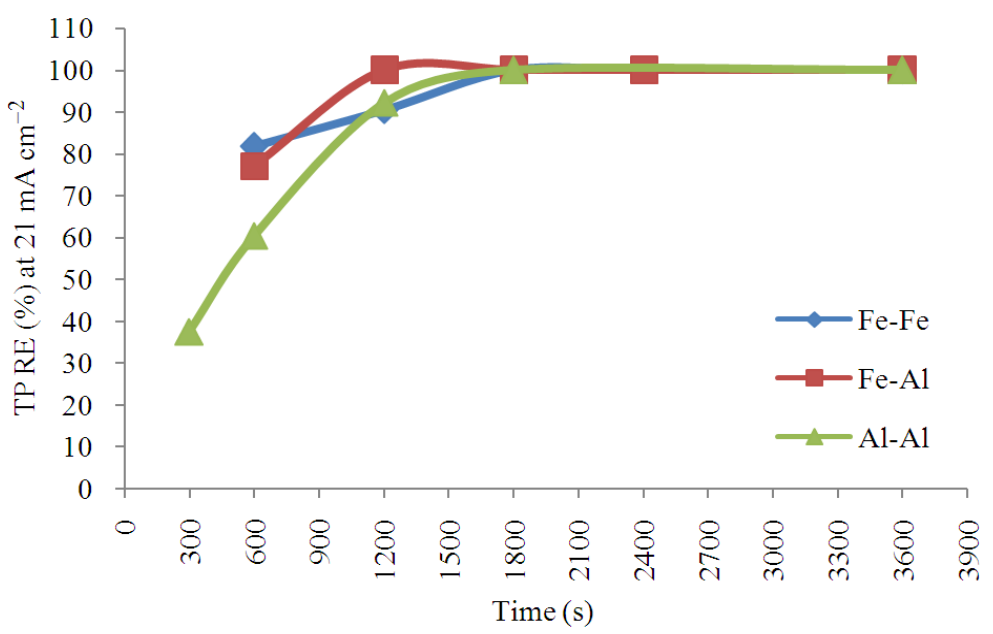

(a)

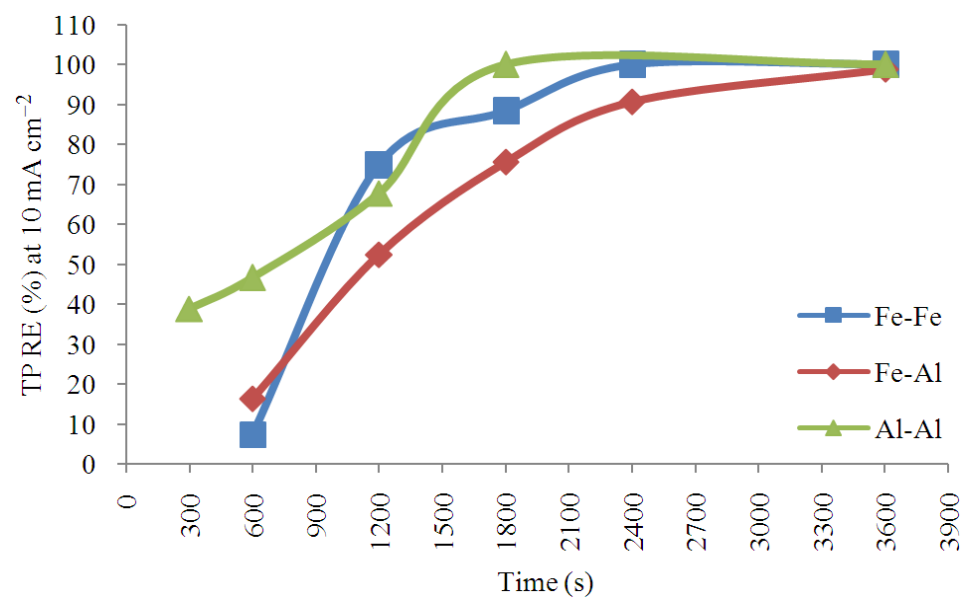

(b) 
S. Rahman and M.S. Borhan / American Journal of Agricultural and Biological Sciences 9 (4): 490-502, 2014
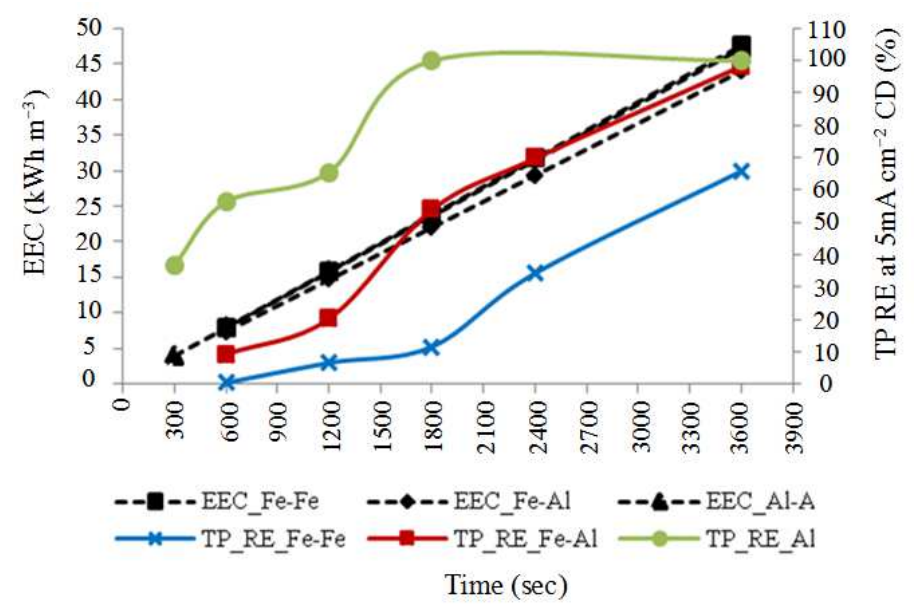

(c)

Fig. 2. The variations of TP Removal Efficiencies (REs) and Electrical Energy Consumptions (EEC) with electrode types at (a) 21, (b) 10 and (c) $5 \mathrm{~mA} \mathrm{~cm}^{-2}$ current densities
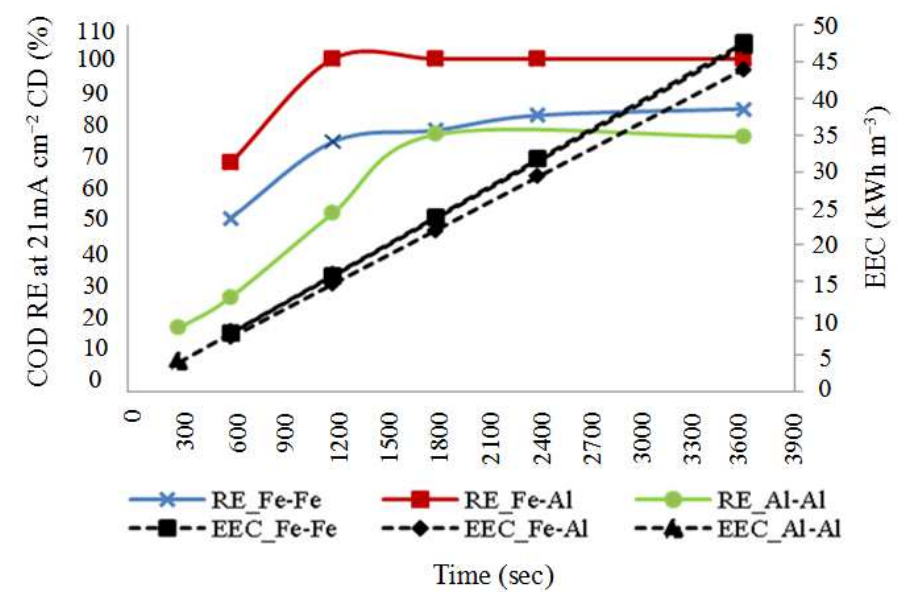

(a)

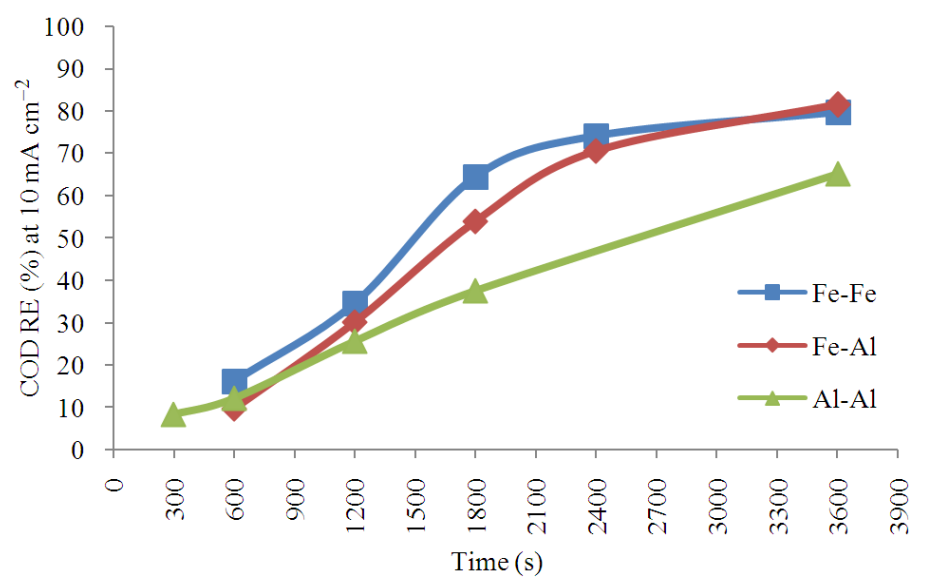

(b) 
S. Rahman and M.S. Borhan / American Journal of Agricultural and Biological Sciences 9 (4): 490-502, 2014

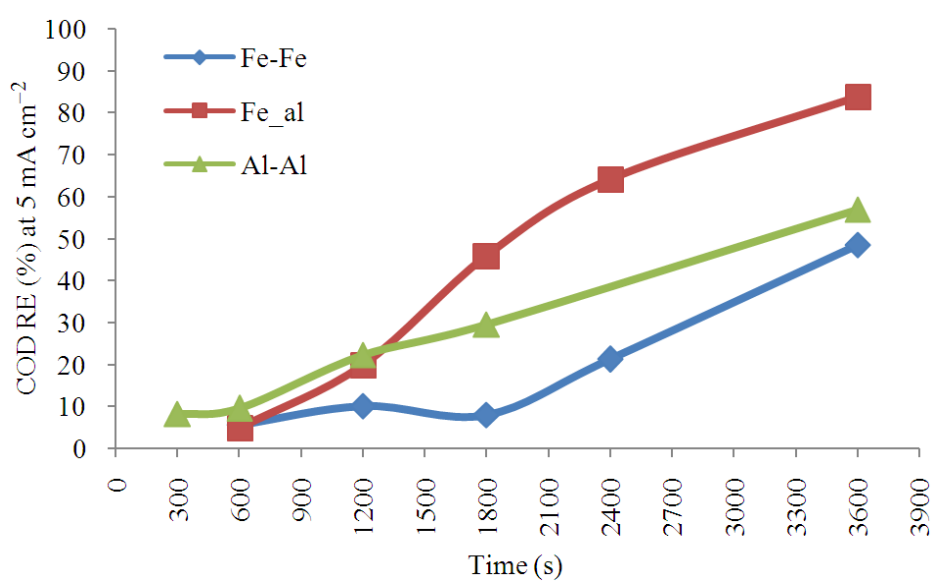

(c)

Fig. 3. The variations of COD Removal Efficiencies (REs) and Electrical Energy Consumptions (EEC) with electrode types at (a) 21, (b) 10 and (c) $5 \mathrm{~mA} \mathrm{~cm}^{-2}$ current densities
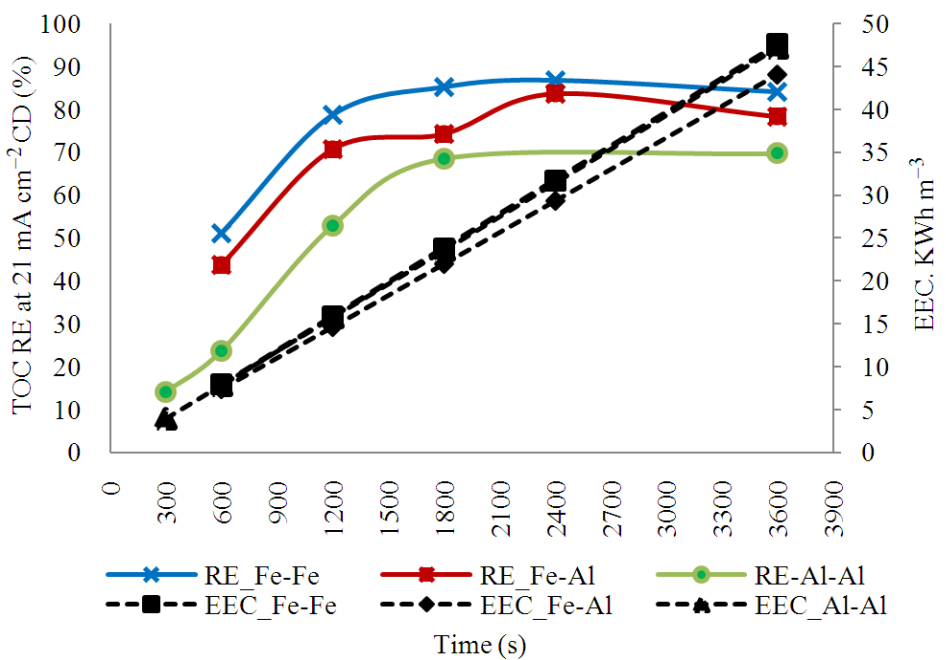

(a)

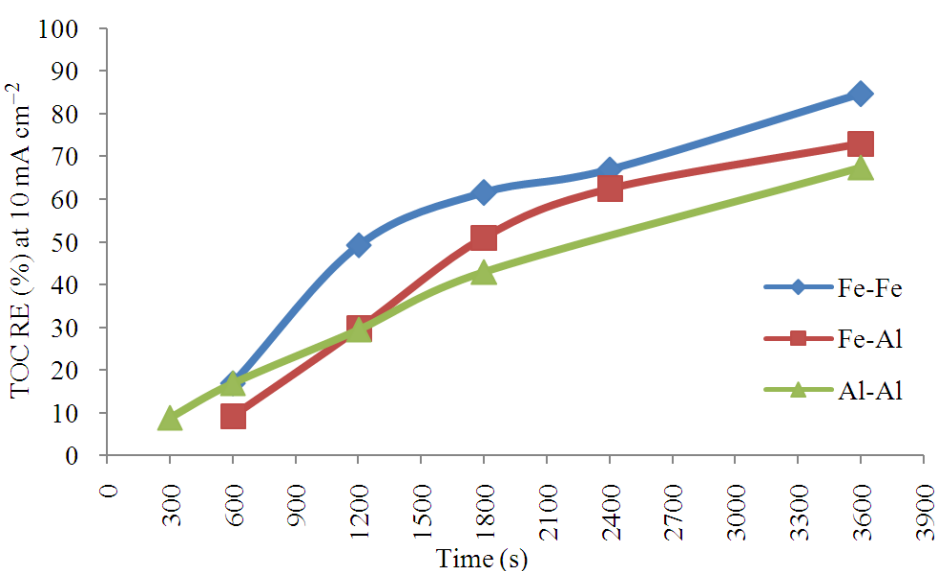

(b) 


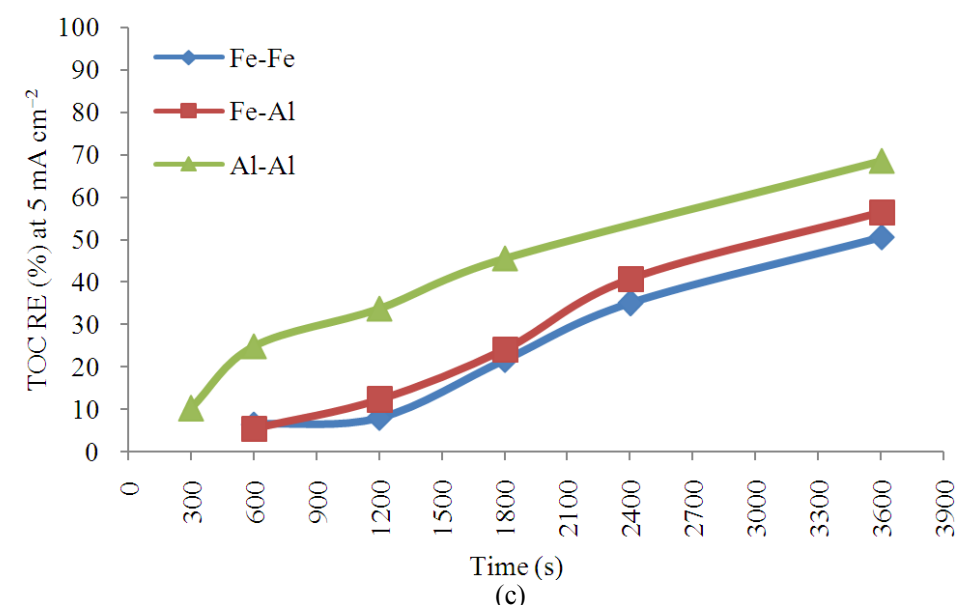

Fig. 4. The variations of TOC Removal Efficiencies (REs) and Electrical Energy Consumptions (EEC) with electrode types at (a) 21 , (b) 10 and (c) $5 \mathrm{~mA} \mathrm{~cm}^{-2}$ current densities

In this study, it was observed that the electrode types responded differently with increased treatment times and levels of applied current densities. At low current density $\left(5 \mathrm{~mA} \mathrm{~cm}{ }^{-2}\right)$, removal efficiencies of COD for all electrode types were $\leq 20 \%$ up to 1200 s treatment time, but removal efficiencies increased as treatment time progressed (Fig. 3c). With longer treatment times (1800 to $3600 \mathrm{~s}$ ), Fe-Al electrodes removed the highest amount of COD (46 to $80 \%$ ) followed by Al-Al (30 to $57 \%$ ) and Fe-Fe (8 to $49 \%$ ) electrodes. Similarly, at $10 \mathrm{~mA} \mathrm{~cm}^{-2}$ current density, $\mathrm{Fe}-\mathrm{Fe}$ electrodes removed the highest COD (60 to $80 \%$ ) followed by Fe-Al (54 to $82 \%$ ) and Al-Al (38 to $65 \%)$ (Fig. 3b).

A previous study reported a maximum $80 \%$ COD removal with an electrolytic system that consisted of alternate $\mathrm{Al}$ and $\mathrm{Fe}$ electrodes (Fe-Al) using treated sludge from textile wastewater (Ciardelli and Ranieri, 2001). In this study, Electrodes Fe-Fe at 10 and $21 \mathrm{~mA}$ $\mathrm{cm}^{-2}$ current densities, removed higher TOC (17 to $85 \%$ and 51 to $100 \%$, respectively) than those of $\mathrm{Fe}-\mathrm{Al}$ ( 9 to $73 \%$ and 44 to $84 \%$, respectively) and $\mathrm{Al}-\mathrm{Al}$ (9 to $67 \%$ and 14 to $70 \%$, respectively) (Fig. $4 a$ and b). On the contrary, Al-Al electrodes removed higher TOC (10 to $69 \%$ ) than those of $\mathrm{Fe}-\mathrm{Fe}$ and $\mathrm{Fe}-\mathrm{Al}$ electrodes at lower current density $\left(5 \mathrm{~mA} \mathrm{~cm}^{-2}\right)$ for all treatment times $(600$ to 3600s) (Fig. 4c). The performance of $\mathrm{Fe}-\mathrm{Fe}$ and $\mathrm{Fe}-\mathrm{Al}$ electrodes at $5 \mathrm{~mA} \mathrm{~cm}{ }^{-2}$ current density were close $(\sim 6$ to $50 \%$ ) for all treatment times. The high removal efficiency for TOC (85\%) was achieved at $1800 \mathrm{~s}$ treatment time at $21 \mathrm{~mA} \mathrm{~cm}^{-2}$ current density with $\mathrm{Fe}-\mathrm{Fe}$ electrodes (Fig. 4a). Previously, Al electrodes showed higher removal efficiency (56\%) than of Fe (35\%) based on COD removal for 1800 s time while treating landfill leach ate effluents (Ilhan et al., 2008).

\subsection{Electrical Energy Consumption (EEC)}

Figure 2 to 4 and Table 2 show the effect of current densities and treatment times on EEC per unit volume of treated wastewater $\left(\mathrm{kWh} \mathrm{m}^{-3}\right)$ coupled with pollutant removal efficiencies. Energy consumption was directly proportional to the current densities applied to the electrolysis system.

At a current density of $21 \mathrm{~mA} \mathrm{~cm}{ }^{-2}, \mathrm{Fe}-\mathrm{Al}$ electrodes removed higher COD $(\sim 100 \%)$ from wastewater than Al$\mathrm{Al}(\sim 54 \%)$ and $\mathrm{Fe}-\mathrm{Fe}(\sim 75 \%)$ electrodes at a similar EEC (14.7 to $15.9 \mathrm{kWh} \mathrm{cm}^{-3}$ ) and treatment time (1200 s) (Fig. 3a). If $70 \%$ COD reduction was considered reasonable, then a1800 s treatment time could be used with similar energy consumptions for all three electrodes (Table 2). On the contrary, TOC removal was higher using the $\mathrm{Fe}-\mathrm{Fe}$ electrodes $(\sim 80 \%)$ with identical energy consumption, treatment time and current density $\left(21 \mathrm{~mA} \mathrm{~m}^{-2}, 1200\right.$ sEEC 14.7 to $\left.15.9 \mathrm{kWh} \mathrm{m}^{-3}\right)$, compared to the $\mathrm{Al}-\mathrm{Al}$ $(\sim 51 \%)$ and $\mathrm{Fe}-\mathrm{Al}(\sim 71 \%)$ electrodes (Fig. 4a).

All three electrodes achieved TP removal efficiencies $>90 \%$ when treating swine liquid manure under identical conditions $\left(21 \mathrm{~mA} \mathrm{~cm}^{-2}, \mathrm{EEC} 14.7\right.$ to $15.9 \mathrm{kWh} \mathrm{m}^{-3}$, $1200 \mathrm{~s}$ ). Electrodes Al-Al with1800 s treatment time showed about $100 \%$ removal of $\mathrm{TP}$ at a low current density level $\left(5 \mathrm{~mA} \mathrm{~cm}^{-2}\right)$ and thus indicated low energy consumption $\left(2.45 \mathrm{kWh} \mathrm{m}^{-3}\right)$ by the $\mathrm{Al}-\mathrm{Al}$ electrodes (Fig. 2c). In contrast, Al-Al electrodes consumed 23.6 $\mathrm{kWh} \mathrm{m}^{-3}$ energies at $21 \mathrm{~mA} \mathrm{~cm}^{-2}$ current density to remove $90 \%$ of TP in $1200 \mathrm{~s}$ treatment time 
S. Rahman and M.S. Borhan / American Journal of Agricultural and Biological Sciences 9 (4): 490-502, 2014

Table 2. Comparison of removal efficiencies, sludge collected and energy consumptions at three current densities for 1800 s treatment time

\begin{tabular}{|c|c|c|c|c|c|c|c|c|c|c|c|}
\hline \multirow{2}{*}{$\begin{array}{l}\text { Current } \\
\text { density } \\
\left.(\mathrm{mA} \mathrm{cm})^{-2}\right)\end{array}$} & \multirow[b]{2}{*}{$\mathrm{EC}$} & \multirow[b]{2}{*}{$\mathrm{pH}$} & \multicolumn{3}{|c|}{ Removal efficiency (\%) } & \multirow{2}{*}{$\begin{array}{l}\text { Electrical Energy } \\
\text { Consumption } \\
\left(\text { EEC) }\left(\mathrm{kWh} \mathrm{m}^{-3}\right)\right.\end{array}$} & \multirow[b]{2}{*}{$\begin{array}{l}\text { Sludge } \\
\left(\mathrm{kg} \mathrm{m}^{-3}\right)\end{array}$} & \multirow{2}{*}{$\begin{array}{l}\text { Specific } \\
\text { energy }(\mathrm{kWh} \\
\left.\text { kg-sludge }^{-1}\right) \\
\end{array}$} & \multicolumn{3}{|c|}{ 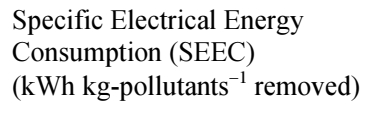 } \\
\hline & & & $\mathrm{TP}$ & COD & TOC & & & & $\mathrm{TP}$ & COD & TOC \\
\hline \multicolumn{12}{|c|}{ Fe-Fe electrode } \\
\hline 5 & 5.9 & 8.4 & 12 & 8 & 22 & 2.1 & 2.80 & 0.75 & 287 & 9 & 11 \\
\hline 10 & 5.9 & 8.7 & 88 & 74 & 62 & 6.8 & 3.20 & 2.13 & 121 & 4 & 12 \\
\hline 21 & 5.8 & 8.4 & 100 & 79 & 85 & 23.8 & 7.50 & 3.17 & 374 & 11 & 31 \\
\hline \multicolumn{12}{|c|}{ Fe-Al electrode } \\
\hline 5 & 5.5 & 8.9 & 54 & 46 & 24 & 1.9 & 1.62 & 1.17 & 55 & 1 & 9 \\
\hline 10 & 5.5 & 8.9 & 76 & 54 & 51 & 6.6 & 3.38 & 1.95 & 137 & 4 & 14 \\
\hline 21 & 5.6 & 8.8 & 100 & 100 & 74 & 22.0 & 7.30 & 3.01 & 346 & 8 & 33 \\
\hline \multicolumn{12}{|c|}{ Al-Al electrode } \\
\hline 5 & 6.7 & 8.4 & 100 & 30 & 46 & 2.5 & 2.43 & 1.03 & 39 & 3 & 6 \\
\hline 10 & 6.6 & 8.3 & 100 & 38 & 43 & 6.8 & 3.22 & 2.11 & 106 & 6 & 17 \\
\hline 21 & 6.6 & 8.4 & 100 & 77 & 69 & 23.6 & 4.70 & 5.02 & 371 & 11 & 38 \\
\hline
\end{tabular}

Specific Electric Energy Consumption (SEEC) per unit mass of sludge removed $\left(\mathrm{kWh} \mathrm{kg-sludge}^{-1}\right)$ were close between Iron (Fe-Fe) and Iron-Aluminum (Fe-Al) based electrodes (Table 2). However, SEEC for Aluminum (AlAl) electrode was slightly higher than those of $\mathrm{Fe}-\mathrm{Fe}$ and $\mathrm{Fe}-\mathrm{Al}$ for all current density levels. The SEEC based on per unit mass of TP removed $\left(\mathrm{kWh} \mathrm{kg-TP}{ }^{-1}\right)$ were ranged from 121-374, 55-346 and 39-371 kWh kg-TP ${ }^{-1}$ for Fe-Fe, $\mathrm{Fe}-\mathrm{Al}$ and $\mathrm{Al}-\mathrm{Al}$ electrode, respectively, for all three levels of applied current densities. Similarly, SEEC per $\mathrm{kg}$ of COD removed $\left(\mathrm{kWh} \mathrm{kg-COD}^{-1}\right)$ were ranged from 4 to 11,1 to 8 and 5 to $10 \mathrm{kWh} \mathrm{kg-COD}{ }^{-1}$ for Fe-Fe, Fe-Al and Al-Al electrodes, respectively, with the same levels of applied current densities. The SEEC per $\mathrm{kg}$ of TOC removed $\left(\mathrm{kWh} \mathrm{kg-TOC}^{-1}\right)$ removed were ranged from 12

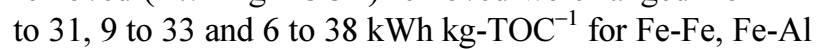
and Al-Al electrodes, respectively.

\subsection{Sludge Characterization}

In this study, the residual Iron $\left(\mathrm{Fe}^{2+}\right.$ and $\left.\mathrm{Fe}^{+3}\right)$ and Aluminum $\left(\mathrm{Al}^{3+}\right)$ ion concentrations in swine manure were not determined. However, the elemental contents of sludge residues was analyzed and quantified. In electrocoagulation process, the coagulant is generated in situ by electrolytic oxidation of an appropriate anode material which was either $\mathrm{Fe}$ or $\mathrm{Al}$ or hybrid (combined $\mathrm{Fe}-\mathrm{Al}$ ) in this study. At the beginning of the electrolysis process, $\mathrm{Al}$ and $\mathrm{Fe}$ ions were produced by anodic dissolution and reacted immediately with hydroxide ions in aqueous medium to produce aluminum hydroxide $\left(\mathrm{Al}(\mathrm{OH})_{2}{ }^{+}\right.$and $\left.\mathrm{Al}(\mathrm{OH})_{3}{ }^{-}\right)$or iron hydroxide $\left(\mathrm{Fe}(\mathrm{OH})_{2}\right.$ and $\left.\mathrm{Fe}(\mathrm{OH})_{3}\right)$, respectively. Subsequently, this process initiated polymerization reactions when metallic hydroxide particles produced had reached sufficient concentration and deposited as sediment (Laridi et al., 2005; Ilhan et al., 2008).

Elemental analyses of electrolysis sludge are listed in Table 3. All electrolysis sludge contains a significant quantity of heavy metals. When $\mathrm{Al}-\mathrm{Al}$ or Fe-Al electrodes were used, it deposited significantly higher Al content in the sludge, but lower $\mathrm{Al}$ content in $\mathrm{Fe}-\mathrm{Fe}$ electrolysis sludge. Similarly, the opposite trend was observed for $\mathrm{Fe}$ content. For the $\mathrm{Fe}-\mathrm{Fe}$ and $\mathrm{Fe}-\mathrm{Al}$ electrodes, significantly higher Fe content was observed in electrolysis treated sludge than in the Al-Al electrode treated sludge. In contrast, when $\mathrm{Fe}-\mathrm{Fe}$ electrodes were used, significantly lower Al content was measured. Although these elements were not measured for the raw swine manure, but when compared with published literature $\mathrm{Cu}, \mathrm{Zn}, \mathrm{Mn}, \mathrm{Ca}, \mathrm{Mg}, \mathrm{K}$, Na content were significantly higher in the electrolysis treated sludge than in the raw manure (Overcash et al., 1978). Total Copper $(\mathrm{Cu})$ and $\mathrm{Zn}$ concentrations in sludge are higher than the North Dakota Pollutant Discharge Elimination Systems (NDPDES) discharge limits (Table 1). Higher element content in sludge is likely due to precipitation of element during electrolysis process.

If manure is treated by any of these electrolysis processes, significant amounts of heavy metals, anion and cations may be deposited as sludge from the swine manure before applying to crop land or any other alternative disposal options. Thus, an electrolysis process would likely improve wastewater quality. Some of the elements (Al, B, Ca, Cu, Fe, K, Mg, Na, P, Pb. S, Si and $\mathrm{Zn}$ ) concentrations in sludge are very high and they can be treated separately to reduce environmental impact. 
Table 3. Elemental analysis of electrolysis sludge

\begin{tabular}{|c|c|c|c|}
\hline \multirow[b]{2}{*}{ Parameters } & \multicolumn{3}{|l|}{ ppm } \\
\hline & $\mathrm{Al}-\mathrm{Al}$ & $\mathrm{Fe}-\mathrm{Fe}$ & $\mathrm{Fe}-\mathrm{Al}$ \\
\hline$\overline{\mathrm{Ag}}$ & $0.15 \mathrm{c} \pm 0.00$ & $1.42 \mathrm{a}^{*} \pm 0.32$ & $0.85 \mathrm{~b} \pm 0.13$ \\
\hline $\mathrm{Al}$ & $148888 a \pm 381787$ & $130 c \pm 164$ & $83377 b \pm 234644$ \\
\hline As & $1.23 \mathrm{c} \pm 0.00$ & $80.74 \mathrm{a} \pm 21.37$ & $34.75 b \pm 6.19$ \\
\hline B & $31.53 \mathrm{a} \pm 2.42$ & $30.50 \mathrm{a} \pm 2.24$ & $26.08 \mathrm{a} \pm 4.97$ \\
\hline $\mathrm{Ba}$ & $2.27 \mathrm{~b} \pm 1.13$ & $5.56 \mathrm{a} \pm 1.12$ & $3.94 \mathrm{ab} \pm 1.17$ \\
\hline $\mathrm{Ca}$ & $12422 \mathrm{a} \pm 5501$ & $13740 \mathrm{a} \pm 8522$ & $12969 a \pm 5620$ \\
\hline $\mathrm{Cd}$ & $1.44 \mathrm{~b} \pm 0.34$ & $19.44 \mathrm{a} \pm 7.20$ & $6.16 \mathrm{~b} \pm 2.21$ \\
\hline $\mathrm{Ce}$ & $1.27 \mathrm{c} \pm 0.83$ & $5.42 \mathrm{a} \pm 0.22$ & $3.11 b \pm 0.347$ \\
\hline Co & $1.28 \mathrm{c} \pm 0.24$ & $7.95 \mathrm{a} \pm 0.98$ & $4.45 b \pm 0.30$ \\
\hline $\mathrm{Cu}$ & $33.76 b \pm 14.05$ & $58.16 \mathrm{a} \pm 7.31$ & $54.53 \mathrm{a} \pm 2.92$ \\
\hline $\mathrm{Fe}$ & $4142 \mathrm{c} \pm 1234$ & $337640 \mathrm{a} \pm 81923$ & $172416 b \pm 23751$ \\
\hline $\mathrm{K}$ & $6853 \mathrm{a} \pm 93.57$ & $3720 \mathrm{~b} \pm 595$ & $4236 \mathrm{~b} \pm 617$ \\
\hline $\mathrm{Li}$ & $4.02 \mathrm{~b} \pm 1.24$ & $1.15 b \pm 0.23$ & $14.16 \mathrm{a} \pm 5.00$ \\
\hline $\mathrm{Mg}$ & $6648 \mathrm{ab} \pm 945$ & $5419 b \pm 1317$ & $10224 a \pm 3416$ \\
\hline $\mathrm{Mn}$ & $95.83 \mathrm{c} \pm 26.48$ & $506.60 \mathrm{a} \pm 56.57$ & $287.29 b \pm 9.92$ \\
\hline $\mathrm{Na}$ & $2469 a \pm 74$ & $1566 b \pm 252$ & $1726 b \pm 210$ \\
\hline $\mathrm{Ni}$ & $9.01 \mathrm{c} \pm 1.93$ & $49.23 a \pm 4.55$ & $32.40 b \pm 1.45$ \\
\hline $\mathrm{P}$ & $6839 a \pm 3738$ & $6917 a \pm 6795$ & $11539 a \pm 6998$ \\
\hline $\mathrm{Pb}$ & $150.97 a \pm 113$ & $1.83 b \pm 1.34$ & $49.33 \mathrm{ab} \pm 12.38$ \\
\hline $\mathrm{S}$ & $5020 \mathrm{a} \pm 1757$ & $2766 a \pm 1515$ & $4144 a \pm 1757$ \\
\hline $\mathrm{Sb}$ & $1.51 \mathrm{a} \pm 0.001$ & $1.51 \mathrm{a} \pm 0.001$ & $1.51 \mathrm{a} \pm 0.001$ \\
\hline $\mathrm{Se}$ & $5.84 a \pm 0.60$ & $1.56 \mathrm{~b} \pm 0.003$ & $2.48 \mathrm{~b} \pm 0.79$ \\
\hline $\mathrm{Si}$ & $39.23 \mathrm{ab} \pm 1.84$ & $50.64 \mathrm{a} \pm 12.02$ & $28.06 \mathrm{~b} \pm 8.13$ \\
\hline Sn & $2.57 \mathrm{a} \pm 1.27$ & $4.93 \mathrm{a} \pm 1.68$ & $3.29 \mathrm{a} \pm 1.12$ \\
\hline $\mathrm{Sr}$ & $23.64 a \pm 11.51$ & $25.81 \mathrm{a} \pm 12.68$ & $26.20 \mathrm{a} \pm 11.51$ \\
\hline $\mathrm{Ti}$ & $9.75 \mathrm{a} \pm 0.45$ & $5.47 b \pm 2.18$ & $7.66 \mathrm{ab} \pm 0.52$ \\
\hline $\mathrm{Tl}$ & $2.36 \mathrm{a} \pm 0.47$ & $2.65 \mathrm{a} \pm 0.60$ & $3.33 \mathrm{a} \pm 1.00$ \\
\hline $\mathrm{V}$ & $8.15 \mathrm{a} \pm 3.35$ & $7.35 a \pm 0.53$ & $8.93 \mathrm{a} \pm 1.52$ \\
\hline $\mathrm{Zn}$ & $414.13 \mathrm{a} \pm 454$ & $168.13 \mathrm{a} \pm 104$ & $267.05 a \pm 168$ \\
\hline
\end{tabular}

*Averages within a column followed by different letters are significantly different at $\mathrm{p}<0.05$ according to Duncan multiple range tests

\section{DISCUSSION}

The EC contents of the liquid manure were decreased during electrolysis process which was also perceived by other researchers (Hong et al., 2013; Kim et al., 2013). The decrease in EC contents during electrolysis was possibly due to the loss of electrolyte ions in the wastewater, transformation of chlorine ion into chlorine gas after playing the role of electron donor and after converting anodically to chlorine which is further converted to hypochlorous acid in the aqueous solution (Costaz et al., 1983; Krstajić et al., 1987). A pH 6.0 is optimal for both Al and Fe based electrodes (Inan et al., 2004). In a neutral and slightly acidic solution (treating medium), Aluminum (Al-Al) based electrodes performed better in removing COD than that of Iron (Fe-Fe) electrodes. In contrast, iron based electrodes performed better in alkaline solutions (Inan et al., 2004; Kobya et al., 2003).
In general, removal efficiencies of pollutants (TP, COD and TOC) from this research showed an increasing trend with treatment duration for all three pollutants and electrodes types under investigation. Generally, the organic concentration in wastewater reduces with the increase in electrolytic time. Previous results reported that at a particular voltage and current density, removal of TP (Kim et al., 2013; Hong et al., 2013; Bensadok et al., 2011; Tchamango et al., 2010), COD (Bensadok et al., 2011; Merzouk et al., 2011; Naïm et al., 2007; Inan et al., 2004; Laridi et al., 2005; Capunitan et al., 2008) and TOC (Merzouk et al., 2011; Cho et al., 2010) increased with increased process/treatment time. In this study, maximum reduction occurred within $1800 \mathrm{~s}$ of treatment began.

The electrodes Al-Al outperformed Fe-Fe and Fe-Al electrodes in removing TP for the same current density levels tested. This was likely because the highest amounts of dissolved aluminum were produced when both anode and cathode were made of aluminum (Al-Al electrodes system) even at a low current density of $5 \mathrm{~mA}$ 
$\mathrm{cm}^{-2}$ (Bensadok et al., 2011). With Al-Al electrodes, pollutant reductions was enhanced through excess active ionization, where aluminum ion combined with the Hydroxyl Ion (OH-) contributed to the generation of higher amounts of aluminum hydroxide $\left(\mathrm{Al}(\mathrm{OH})_{3}\right)$ (Hong et al., 2013; Sposito, 1996). At high current density $\left(21 \mathrm{~mA} \mathrm{~cm}{ }^{-2}\right.$ ), TP removal was comparable among all three electrode types, but at low current density $\left(5 \mathrm{~mA} \mathrm{~cm}^{-2}\right)$, the $\mathrm{Al}-\mathrm{Al}$ electrodes outperformed $\mathrm{Fe}-\mathrm{Fe}$ and $\mathrm{Fe}-\mathrm{Al}$ electrodes. This indicated that applied current densities have an effect on the response of electrode materials.

Among the electrode types, the Fe-Al electrodes outperformed $\mathrm{Fe}-\mathrm{Fe}$ and $\mathrm{Al}-\mathrm{Al}$ electrodes for removing COD at 5 and $21 \mathrm{~mA} \mathrm{~cm}^{-2}$ current densities (Fig, 3a and $\mathbf{c}$, but $\mathrm{Fe}-\mathrm{Fe}$ electrodes resulted in better COD removal at $10 \mathrm{~mA} \mathrm{~cm}^{-2}$ than the other electrodes (Fig. 3b). For the same treatment times (1200 s) at a high current density $\left(21 \mathrm{~mA} \mathrm{~cm}^{-2}\right)$, COD removal efficiency of Fe-Al electrodes was about $100 \%$, which were about 1.9 and 1.3 times higher than those of $\mathrm{Al}-\mathrm{Al}$ and $\mathrm{Fe}-\mathrm{Fe}$ electrodes, respectively (Fig. 3a). The Fe-Fe electrodes performed the best in removing COD followed by Hybrid (Fe-Al) and $\mathrm{Al}-\mathrm{Al}$ electrodes at high current density levels. The COD removal efficiencies of hybrid electrodes were in-between $\mathrm{Fe}-\mathrm{Fe}$ and Al-Al. Laridi et al. (2005) stated that at 1500 and $2000 \mathrm{~mA}$ current levels iron electrodes resulted in significantly greater COD reductions than that of aluminum using swine liquid manure for a 1800 s treatment time. It was demonstrated in a bench scale study using neutral and alkaline textile wastewater that the Fe-Fe was more efficient than Al-Al electrodes in removing COD and electrode's efficiency was reversed when wastewater medium was acidic (Kobya et al., 2003). In our study, the final pH recorded for all electrodes types were ranged from 9-9.5. Thus, slightly basic swine liquid manure with iron based electrodes ( $\mathrm{Fe}-\mathrm{Fe}$ and $\mathrm{Fe}-\mathrm{Al})$ electrodes resulted higher COD reduction than Al-Al electrodes. This research indicated that Al-Al electrodes at low current density (5 $\mathrm{mA} \mathrm{cm}{ }^{-2}$ ) were sufficient in removing TP from swine manure tested. Similarly, Bensadok et al. (2011) reported that $\mathrm{Al}-\mathrm{Al}$ electrode reduced $80 \% \mathrm{COD}$ and $60 \%$ phosphate $\left(\mathrm{PO}_{4}{ }^{3-}, 60 \%\right)$ from dairy wastewater when current density, treatment time, $\mathrm{pH}$ and Sodium Chloride $(\mathrm{NaCl})$ concentration were $5 \mathrm{~mA} \mathrm{~cm}^{-2}, 120 \mathrm{~s}$, 6.6 and $1.5 \mathrm{gL}^{-1}$, respectively. They reported that the energy consumption for these conditions was found to be near $0.03 \mathrm{kWh} / \mathrm{kg}$ of COD removal.
Similar to pollutants removal efficiencies and EECs, sludge productions $\left(\mathrm{kg} \mathrm{m}^{-3}\right)$ were increased with increasing applied current density levels (Table 2). The highest amount of sludge was produced at an applied current level of $21 \mathrm{~mA} \mathrm{~cm}$ for all electrode types. Sludge productions were 7.5, 7.3 and $4.7 \mathrm{~kg} \mathrm{~m}^{-3}$ for $\mathrm{Fe}-$ $\mathrm{Fe}, \mathrm{Fe}-\mathrm{Al}$ and $\mathrm{Al}-\mathrm{Al}$ electrodes, respectively. It is well known that for an electro-coagulation process using sacrificial electrodes, the sludge amount and the energy consumption increase with the treatment time increases. Our results also showed a good agreement with a previous study that reported a higher amount of sludge with $\mathrm{Fe}$ electrodes than that of $\mathrm{Al}$ while treating swine liquid manure obtained from bio-filtration process when treated for $1800 \mathrm{~s}$ (Laridi et al., 2005). The Fe-Fe electrodes transfer higher numbers of $\mathrm{Fe}$ ions into solution and they produce a higher amount of sludge (Ilhan et al., 2008). However, higher amounts of sludge may accrue higher disposal cost.

Overall low SEECs per kg of pollutants (TP, COD and TOC) were estimated for Al-Al electrodes. The lowest SEEC per $\mathrm{kg}$ of TP were estimated for Al-Al electrodes at a current density of $7 \mathrm{~mA} \mathrm{~cm} \mathrm{~cm}^{-2}\left(39 \mathrm{kWh} \mathrm{kg-TP^{-1 }}\right)$

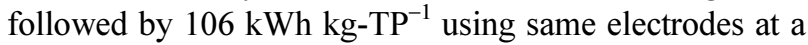
current density of $10 \mathrm{~mA} \mathrm{~cm}{ }^{-2}$. Similarly, low SEEC per $\mathrm{kg}$ of $\mathrm{COD}^{-1}$ and per $\mathrm{kg}$ of $\mathrm{TOC}^{-1}$ removal were also calculated for Al-Al. Calculated SEECs were 3 and $6 \mathrm{kWh}$ $\mathrm{kg}-C O D^{-1}$ and 6 and $17 \mathrm{kWh} \mathrm{kg-TOC}{ }^{-1}$ for 5 and $10 \mathrm{~mA}$ $\mathrm{cm}^{-2}$ current density, respectively, with Al-Al electrodes. With Al-Al electrodes, the pollutants reductions were enhanced through excess active ionization, where aluminum ion combined with the hydroxyl ion (OH-) and contributed to the generation of higher amounts of Aluminum Hydroxide $\left(\mathrm{Al}(\mathrm{OH})_{3}\right)$ (Hong et al., 2013; Sposito, 1996). The elemental analysis indicated sedimentation of metal residue in a sludge from runoff wastewater during an electrolysis process. However, residues were rich with respective metal of the electrodes tested with the electrolysis process. Therefore, this study clearly indicated the effect electrolysis in removing metals presented in the swine wastewater.

\section{CONCLUSION}

This research investigated the effects of current density levels on the electrolysis of swine liquid manure with electrodes consisting of either Fe-Fe, Fe$\mathrm{Al}$, or Al-Al electrode materials. We obtained the following results in this study. 
- The removal efficiencies of TP, COD and TOC were positively correlated with increasing treatment times and applied current densities $(5,10$ and $21 \mathrm{~mA}$ $\mathrm{cm}^{-2}$ ) for each electrode materials

- The current densities applied to the electrolysis system were directly proportional to the energy consumption and sludge generated

- $\quad$ Aluminum (Al-Al) electrode consumed low energy at a low current density level with high TP removal efficiency $(100 \%)$

- Hybrid electrode (Fe-Al) outperformed Al-Al and FeFe electrodes in treating COD at similar EEC level

- Iron Electrode (Fe-Fe) outperformed hybrid and Al electrodes in treating TOC at similar EEC

- The aluminum electrodes showed low SEEC per kg of TP (39 kWh kg-TP ${ }^{-1}, 5 \mathrm{~mA} \mathrm{~cm}{ }^{-2}$ ) followed by 106 $\mathrm{kWh} \mathrm{kg-TP^{-1 }}$ at a current density of $10 \mathrm{~mA} \mathrm{~cm}^{-2}$. The SEEC per kg of $\mathrm{COD}^{-1}$ and per kg of $\mathrm{TOC}^{-1}$ removal were similar among electrodes tested

- Electrolysis process deposited significant amount of elements in the sludge, thus likely to improve wastewater quality

\section{ACKNOWLEDGEMENT}

Financial support from North Dakota Pork Council and State Board of Agricultural Research and Education (SBARE) are gratefully acknowledged. The authors also acknowledge Swine Research Center of North Dakota State University for supplying swine effluents for this study.

\subsection{Authors Contribution}

Both authors have contributed equally. Md. Borhan has conducted the experiment and data analysis. Shafiqur Rahman has designed the experiment, written the manuscript and interpreted the data.

\subsection{Ethics}

This manuscript has neither been published, nor under consideration for publication or in press elsewhere concurrently.

\section{REFERENCES}

APHA, 2005. Standard Methods for the Examination of Water and Wastewater. 2nd Edn., American Public Health Association, Washington, D.C., ISBN-10: 0875530478 .
Bensadok, K., N.E. Hanafi and F. Lapicque, 2011. Electrochemical treatment of dairy effluent using combined $\mathrm{Al}$ and $\mathrm{Ti} / \mathrm{Pt}$ electrodes system. Desalination, 280: 244-251.

DOI: $10.1016 /$ j.desal.2011.07.006

Capunitan, J.A., C.G. Alfafara, V.P. Migo, J.L. Movillon and E.I. Dizon et al., 2008. Decolorization and Chemical Oxygen Demand (COD) reduction of sugar refinery Spent IonExchange-Process (SIEP) effluent by electrochemical treatment methods. Philippine Agric. Scientist, 91: 416-425.

Cho, J.H., J.E. Lee and C.S. Ra, 2010. Effects of electric voltage and sodium chloride level on electrolysis of swine wastewater. J. Hazardous Materials, 180: 535-541.

DOI: $10.1016 /$ j.jhazmat.2010.04.067

Ciardelli, G. and N. Ranieri, 2001. The treatment and reuse of wastewater in the textile industry by means of ozonation and electroflocculation. Water Resources, 35: 567-72. PMID: 11229013

Costaz, P., J. Miquel and M. Reinbold, 1983. Simultaneous electroflotation and disinfection of sewage. Water Res., 17: 255-262.

DOI: 10.1016/0043-1354(83)90178-1

Hong, K., D. Chang, H. Bae, Y. Sunwoo and J. Kim et al., 2013. Electrolytic removal of phosphorus in wastewater with noble electrode under the conditions of low current and constant voltage. Int. J. Electrochemical Sci., 8: 8557-8571.

Ilhan, F., U. Kurt, O. Apaydin and M.T. Gonullu, 2008. Treatment of leachate by electrocoagulation using aluminum and iron electrodes. J. Hazardous Materials, 154: 381-389.

DOI: $10.1016 /$ j.jhazmat.2007.10.035

Inan, H. and E. Alaydın, 2014. Phosphate and nitrogen removal by iron produced in electrocoagulation reactor. Desalinat. Water Treatment, 52: 1396-1403. DOI: $10.1080 / 19443994.2013 .787950$

Inan, H., A. Dimoglo, H. Simsek and M. Karpuzcu, 2004. Olive oil mill wastewater treatment by means of electro-coagulation. Separat. Purificat. Technol., 36: 23-31.

DOI: $10.1016 / \mathrm{S} 1383-5866(03) 00148-5$

Kim, D., W. Kim, C. Yun, D. Son and D. Chang et al., 2013. Agro-industrial wastewater treatment by electrolysis technology. Int. J. Electrochemical Sci., 8: 9835-9850. 
Kobya, M., O.T. Can and M. Bayramoglu, 2003. Treatment of textile wastewaters by electrocoagulation using iron and aluminum electrodes. J. Hazard Materials, 100: 163-178. DOI: $10.1016 / \mathrm{S} 0304-3894(03) 00102-\mathrm{X}$

Krstajić, N., V. Nakić and M. Spasojević, 1987. Hypochlorite production. I. A model of the cathodic reactions. J. Applied Electrochem., 17: 77-81. DOI: 10.1007/BF01009133

Laridi, R., P. Drogui, H. Benmoussa, J.F. Blais and J.C. Auclair, 2005. Removal of refractory organic compounds in liquid swine manure obtained from a biofiltration process using an electrochemical treatment. J. Environ. Eng., 131: 1302-1310. DOI: 10.1061/(ASCE)0733-9372(2005)131:9(1302)

Li, L. and Y. Liu, 2009. Ammonia removal in electrochemical oxidation: Mechanism and pseudokinetics. J. Hazardous Materials, 161: 1010-1016. DOI: $10.1016 /$ j.jhazmat.2008.04.047

Liang, Q., 2011. Simultaneous phosphorus and nitrogen removal using aluminum based water treatment residual. M.Sc. Thesis, Colorado State University.

Liu, Y., L. Li and R. Goel, 2009. Kinetic study of electrolytic ammonia removal using $\mathrm{Ti} / \mathrm{IrO}_{2}$ as anode under different experimental conditions. J. Hazardous Materials, 167: 959-965. DOI: 10.1016/j.jhazmat.2009.01.082

Merzouk, B., M. Yakoubi, I. Zongo, J.P. Leclerc and G. Paternotte et al., 2011. Effect of modification of textile wastewater composition on electrocoagulation efficiency. Desalination, 275: 181-186. DOI: 10.1016/j.desal.2011.02.055

Morse, G.K., S.W. Brett, J.A. Guy and J.N. Lester, 1998. Review: Phosphorus removal and recovery technologies. Sci. Total Environ., 212: 69-81. DOI: $10.1016 / \mathrm{S} 0048-9697(97) 00332-\mathrm{X}$
Naïm, M., S. Bhat, K.N. Rankin, S. Dennis and S.F. Chowdhury et al., 2007. Solvated Interaction Energy (SIE) for scoring protein-ligand binding affinities. 1. Exploring the parameter space. J. Chem. Inform. Model., 47: 122-33.

PMID: 17238257

NDPDES, 2009. General permit for stormwater discharges from industrial activities (NDR090000). North Dakota Pollutant Discharge Elimination Systems.

Overcash, M.R., J.W. Gilliam, F.J. Humenik and P.W. Westerman, 1978. Lagoon pretreatment: Heavy metal and cation removals. Water Environ. Federat., 50: 2029-2036.

Regy, S., D. Mangin, J.P. Klein and J. Lieto, 2002. Phosphate recovery by struvite precipitation in a stirred reactor. Laboratoired'Automatiqueet de Genie des Procedes (LAGEP).

SAS, 1999. SAS user's guide: Statistics. Version 8; SAS Institute, Cary, NC.

Sposito, G., 1996. The Environmental Chemistry of Aluminum. 2nd Edn., CRC Press, New York.

Steel, R.C.D., J.H. Torrie and D.A. Dickey, 1997. Principles and Procedures of Statistics: A Biometrical Approach. 3rd Edn., McGraw-Hill, Singapore, ISBN-10: 0070610282, pp: 666.

Tchamango, S., C.P. Nanseu-Njiki, F. Ngameni, A. Hadjiev and A. Darchen, 2010. Treatment of dairy effluents by electrocoagulation using aluminium electrodes. Sci. Total Environ., 408: 947-952. DOI: $10.1016 /$ j.scitotenv.2009.10.026

Udert, K., T. Larsen and W. Gujer, 2006. Fate of major compounds in source-separated urine. Water Sci. Technol., 54: 413-420.

PMID: 17302346 